\title{
Lower Class Insurgency and the Political Process: The Response of the U.S. Unemployed, 1890-1940*
}

\author{
HAROLD R. KERBO, California Polytechnic State University, \\ San Luis Obispo \\ RICHARD A. SHAFFER, California Polytechnic State University, \\ San Luis Obispo
}

\begin{abstract}
This paper examines the level of protest activity by the unemployed in the United States between 1890 and 1940 as a test of the value of a political process model for explaining social movement activity. Data on protest events and elite attitudes towards the unemployed were collected from newspaper articles. Voting behavior was used as an indicator of contested elections and unemployment levels were reflected by available indicators. Consistent with previous research on lower-and working-class mobilization, a change in the political environment was key to the extensive protest by the unemployed in the 1930s. Toward the end of the 1920s, and especially in the early 1930s, elites were no longer simply making public statements about the problem of unemployment, but were also discussing the need for aid programs. In the context of this new political environment, elections were once again contested in the 1930s, and extensive protest began in 1930, even before unemployment hit its high point in 1933. Thus, it was not simply deprivation, but the changed political environment which legitimized the issue of unemployment and created prospects for reform, which in turn helped produce the massive protest of the 1930s.
\end{abstract}

The primary goal of the research reported in this paper is to further understanding of the development, and lack of development, of protest by the unemployed in the United States between 1890 and 1940. The focus is on resource mobilization, and more specifically, on a political process perspective on the development of social movements, and the interaction between political environment and deprivation in the mobilization of social movement activities.

We examine a specific condition (unemployment) likely to produce hardship, presuming that unemployment creates hardship for the vast majority of the unemployed. It could, of course, be argued that the pain of unemployment is eased somewhat in agricultural settings, or through the provision of extensive welfare benefits. For the period 1890 to 1940 , however, neither of these factors had much effect on the impact of unemployment. By the 1890s, most of the labor force was urban (U.S. Bureau of Census 1975), and the best historical descriptions of unemployment during this time period do not credit welfare support or food resources from private lands as significant factors in reducing the impact of unemployment (Feder 1936; Garraty 1978.) Our approach overcomes some limitations of past research which typically focused on all collective action events in a specified time period, often involving diverse issues and interest groups (Kerbo and Shaffer 1986; Snyder 1975:275; Tilly 1984). We examine a specific source of hardship affecting a segment of the population which can be followed over an extended time period in order to understand the changing parameters associated with collective action. ${ }^{1}$

* Correspondence to: Kerbo, Social Sciences Department, California Polytechnic State University, San Luis Obispo, CA 93407

1. In previous work we have argued for the use of "group analysis" over "event analysis" in the study of social 


\section{Resource Mobilization and a Political Process Model}

With a shift in sociological paradigms, and with empirical problems for deprivation theories, the works by such theorists as McCarthy and Zald (1977), Oberschall (1973), and Gamson (1975) established the importance of a resource mobilization theory of social movements. The focal point of resource mobilization theory is a change in the balance of resources between insurgents and supporters of the status quo. When, for example, the defenders of the status quo become weaker and/or insurgents who have been locked out of the traditional political process gain resources with which to challenge the status quo, a social movement is likely to emerge or become stronger. Thus, in the resource mobilization perspective the level of deprivation, especially economic deprivation, and frustration experienced by potential insurgents is rejected as a key source of social movements. More recently, the movement toward theoretical maturity has brought with it criticism and a diversity of perspectives within a more general resource mobilization theory (e.g., see Kerbo 1982; Tarrow 1988). For example, it is now generally recognized that McCarthy and Zald (1977) initially went too far in rejecting the role of deprivation and other social psychological factors in helping generate social movements (Hirsch 1990; Klandermaus 1984; Oliver 1980). While some form of perceived deprivation is widespread in almost any society, as McCarthy and Zald stress, there are certainly changes in the level of this perceived deprivation which can help lead to insurgent mobilization (McAdam 1982).

Equally important has been a trend toward greater recognition of political variables behind social movement activity, as first introduced by Piven and Cloward (1977) and Gamson (1975) (see Tarrow 1988:427). This "political process model" of social movements generally fits within a resource mobilization perspective, but focuses more on how changes in the political process can at times create new political opportunities for insurgents. For example, McAdam (1982:41) suggests that political elites may at times need to placate less powerful groups. According to this approach, processes such as war; changes resulting from industrialization, international political realignments, and prolonged unemployment; and widespread demographic changes make the use of repression by political elites less likely (Goldstone 1980, 1986). Tilly (1978) and Piven and Cloward (1977), on the other hand, focus more on how political competition can create political opportunities for insurgent mobilization. More specifically, Tilly (1978) has stressed how social movement activities seem concentrated around highly contested elections. During these periods, potential movement activists may perceive that an increase in the number of movement participants can result in increased political opportunities.

Piven and Cloward (1977) have stressed how political opportunities may be created when political competition has resulted from a major political party's decline. In this situation the declining party may give material and ideological support to lower class groups in order to broaden the party's voter constituency. Such support can enhance insurgent mobilization by legitimizing lower-class issues and reducing oppression which had previously made social movement organization and mobilization more difficult.

Other recent critiques of the resource mobilization perspective have focused on the neglect of what may generally be called psychological variables in the mobilization process (Klandermans 1984; Oliver 1980). This criticism, which is especially directed toward the work by Olson (1965), stresses that people do not just respond to an objective change in the resources available to press for their interests with social movement activity. Social psychological processes must be activated and carried out in face-to-face interactions in order to mobilize

movements. In contrast to studies which code all events of political violence or protest, no matter what the issue or background of the group involved (event analysis), we have focused on only one issue-unemployment-and protest only by people who are unemployed. "Group analysis" describes this method (following Snyder 1975), but, of course, the unemployed who are involved in protest over time do not form a specific and unchanging group in a strict sense. 
participants (Hirsch 1990). In part, this psychological aspect of resource mobilization is included in what McAdam (1982) describes as "cognitive liberation" that allows social movement members to legitimize their demands in their own eyes, and thus makes them feel more justified to act. Klandermans (1984) also includes under these social psychological variables the expectation that others will get involved in the social movement and their estimation of the probability of success if they become active in protest activities.

Though research on this subject remains incomplete, we find some empirical support for the political process model. For example, in their study of farm worker movements in the United States, Jenkins and Perrow (1977) concluded that increased outside support (both symbolic and concrete) due to changes in the political process, rather than changes in the level of discontent, were most important for the growth of the United Farm Workers movement in the 1960s. Jenkins and Perrow's data tend to support this argument, with one significant weakness; they assumed a consistent level of deprivation among farm labor. For an adequate empirical comparison of a political process model and deprivation theory such an assumption must be empirically demonstrated.

In their historical analysis of "poor people's movements," Piven and Cloward (1977) make the same general argument. While continuing to stress the significance of a changing level of hardship in generating many collective challenges, Piven and Cloward (1977:9) also point to the support (or at least reduced opposition) for lower class groups that may result from a changed political environment. One elite faction may go to the lower class for electoral support, and may even help define social movement goals and demands to gain this support. It was this new elite support, according to Piven and Cloward (1982, 1977, 1971), which helped account for the extensive mass protest by labor and the unemployed during the 1930s and by blacks during the 1950s and 1960s in the United States.

McAdam's (1982) empirical research on the rise of the civil rights movement has also given support to a political process model as well as the psychological dimension of mobilization. While McAdam found that an increase in political opportunities was important, he also emphasized that "cognitive liberation" and "indigenous organization strength" were equally important factors in mobilizing insurgents. Cognitive liberation is the new attitude that movement member grievances are legitimate and that their push for social change can be successful. By indigenous organizational strength, we mean the capacity to recruit members and establish a communication network. All of these factors are seen by McAdam (1982:51) as interrelated, and the result of change in the political process; his data show these factors were crucial to the development of the civil rights movement.

Explanations of industrial conflict have been moving in the same direction. Snyder (1975) shows that before World War II, political process changes, which provided political opportunities for achieving goals through strike activities, were more important in explaining strikes than were changes in economic conditions. From his finding that the "political party affiliation of Congressional and Presidential office holders have a strong impact on strike fluctuations from 1900 to 1948 " in the United States, Snyder (1975:274) suggests that the "attitudes" of government officials toward labor influenced labor's ability to demand greater rewards from the capitalist class. These demands, in turn, often resulted in strikes.

The major thrust of Tilly's "power struggles" theory (see Snyder and Tilly 1972; Tilly 1978; Tilly, Tilly, and Tilly 1975) is that collective action and collective violence are the result of groups with conflicting interests mobilized by political crisis or the possibility of achieving demands during power changes. Major elections which are closely contested often provide the setting for such mobilization and thus, collective violence should be located around these particular election periods. Tilly's research, especially in France, does show some support for his power struggles theory (Snyder and Tilly 1972; Tilly, Tilly, and Tilly 1975).

Finally, with respect to strikes and the social psychological dimensions of mobilization, Klandermans' (1984) study of strike participants found that workers' perceptions of the 
chances that other workers would participate and that the strike would succeed all influenced whether or not individual workers would participate in a strike. Hirsch (1990) found similar social psychological variables important in understanding the mobilization of student protestors.

\section{Measures of Political Environment and Predicted Relationships}

Tarrow (1988) has recently pointed out the need for more theoretical and empirical work on the idea of political opportunities and the changes in political environment behind the development of social movements. He notes that political opportunities are most likely a cluster of variables, involving both objective and subjective (or psychological) factors. We agree with this view and stress the need for research with more specific measures of the different aspects of political environment to determine which aspects are more important for mobilizing social movement activity. A problem, of course, is that these precise measures are difficult to come by, and that several aspects of a change in political environment often occur together, making it difficult to determine which are most important in stimulating social movements. As pointed out earlier, previous attempts to measure the effects of political environment have not also adequately measured the level of hardship which may motivate movement activity.

In addition to our analysis of the relationship between hardship (the level of unemployment) and social movement activity by the unemployed, we have measured several aspects of political environment change cited in previous theory and research. Our measures of political environment change focus on the effects of elite statements about the problems of unemployment and about programs to aid the unemployed, and elections. We measured types of elites and the extent to which they publicly acknowledged the issue of unemployment between 1890 and 1940, thus helping legitimize unemployment as an issue. We also measured the extent to which elites publicly discussed specific welfare programs that if passed into law would aid the poor and unemployed. We included data on election years to examine the thesis that protest activity is clustered around election years. Most importantly with election years, we measured the extent to which these elections were contested, which indicates the chances of the political party out of power winning the election and carrying out political change.

We expected to find that from 1890 to 1940 , the level of unemployment itself was unrelated to protest activity by the unemployed. Rather, protest by the unemployed should become more likely when unemployment is high and 1) the issue of unemployment is legitimized by elites, 2) specific programs to aid the unemployed are discussed by elites but have not yet been acted upon by the government, and 3) when contested elections in which both of the above conditions ( 1 and 2 ) occur. These specific changes in political environment give legitimacy to complaints by the unemployed. More importantly, though, they contribute to the realization that mobilization may be effective, because elites are actually discussing aid programs and political action taken in contested elections makes implementation of these programs even more likely.

\section{Data and Methods}

In contrast to industrial violence, researchers have no easily accessible source of data when attempting to measure collective protest by groups such as the unemployed. Following the approach of other researchers (e.g., Jenkins and Eckert 1986; Jenkins and Perrow 1977; McAdam 1983; Paige 1975; Snyder and Tilly 1972; Stohl 1976; Tilly, Tilly, and Tilly 1975), we 
take our data on protest by the unemployed and elite attitudes toward the unemployed primarily from the thoroughly indexed New York Times. In addition to extensive defense of the New York Times as a data source (see especially, Paige 1975), empirical examinations of the validity and reliability of data collection from major newspapers have also been conducted (see Danzger 1975; Kielbowicz and Scherer 1986; Olzak 1989; Snyder and Kelly 1977). This research has found newspaper sources for protest events generally acceptable and more complete than any other source.

In our data collection procedure on protest events, research assistants examined the New York Times Index for the location of newspaper articles about these events from 1890 to 1940 , read the original articles in the New York Times, and coded the necessary information. Only protest events primarily composed of the unemployed themselves (including public assistance recipients) were coded. This coding procedure excluded events that were primarily strikes or other collective actions by the employed. Some of these events in the 1930s (such as strikes) were on the behalf of the unemployed, but it was difficult to separate out the most important issue behind the strike. Specifically, under the subject-protest by the unemployed-we coded the number involved; the location, target, and goals of the action; and the number arrested, injured, and killed. A total of 303 protest events were located, read, and coded.

To check coding accuracy, the authors randomly selected six years (1908, 1913, 1920, 1921, 1922, and 1929) and followed the same coding procedures. The overall agreement rate was 89 percent. As another means of checking the accuracy of coding (and the essence of New York Times reportage), one of the authors selected key time periods and examined every page of the New York Times, reading articles related to our subject matter. This method was employed to make sure the New York Times Index was accurate and correctly utilized in this research. Reading the entire Index was impossible, but we found some key index headings most likely to contain the information required (especially "unemployment"). The years and months selected for this coding check were chosen because they were election years with high unemployment, but with very few protest events located by our coding procedure. The time periods examined were January to March 1894, August to November 1894, August to November 1896, and August to November 1908. This method strongly confirmed the validity of our coding procedures.

It is important to note some specific limitations of our data source for protest events. As might be expected, other studies (e.g.; Kielbowicz and Scherer 1986; Snyder and Kelly 1977) have shown that newspapers are somewhat selective in their coverage of collective violence and protest. Newspapers are more likely to run stories on bigger events, and events closer to the geographical area where the newspaper is published. Thus, our data are no doubt biased in these respects. For example, close to three-fourths of our protest events were in the Northeast. But we have no reason to believe the Northeastern United States differed substantially with respect to protest by the unemployed. Probably the most important limitation of our data collection method was the underreporting of rural protest. Historical works on the $1930 \mathrm{~s}$ suggest protest in rural areas was significant, but only 2 percent of our protest events were located in rural areas. We assume that New York City's level of protest was not unique, and that it can be used as an indicator of urban protest nationwide.

We employed two other methods to check the accuracy of our data source for protest events. First, using the same key time periods previously noted for validity checks, every page of the San Francisco Chronicle was examined for reports of protest. Both the New York Times and San Francisco Chronicle included relatively small local events not found in the other newspaper; but the overall number of events, though often not the same protest events, were close for both newspapers. Second, reports given about collective protest by the unemployed in major historical works were checked against our New York Times data (these works included Feder 1936; Garraty 1978; Goldman 1953; Hofstader 1955; Keyssar 1986; Schlesinger 1957, 1959, 1960; Piven and Cloward 1971, 1977). The New York Times data were very complete for 
the total time period examined, and generally conformed to the descriptions of the magnitude of protest contained in these historical works.

Our data collection procedure on elite attitudes toward the unemployed resembled our procedure for data collection on protest events. Research assistants located newspaper articles in the New York Times Index from 1890 to 1940 indicating that a specific person, official organization (business group, religious group, or other voluntary organization), or government agency had voiced an opinion about conditions for the unemployed. The original New York Times article was then read, and the necessary information coded. In order to avoid inflating the relationship between protests and elite statements, separate groups of coders worked on the two types of news information. Initially, our definition of elites and influential organizations was very broad for the data collection process. Our working assumption was that if a statement about the unemployed by an individual or group was emphasized in the New York Times Index, the group or individual should be considered elite. This was not always the case, of course. Unfamiliar names were checked in biographical sources when articles provided insufficient information. The level of elite status was coded as city level, state level, or national level for organizations, and for the position held in the case of individuals. Elites and organizations were alsn divided into institutional sectors (e.g., political, business, religious, charity, and other voluntary organizations). Each person's position and each organization's characteristics were coded, and a separate analysis was made for national level political elites (the president, vice-president, cabinet members, top federal government agencies, and members of congress). There was a strong correlation $(r=.79)$ between the presence of statements by national political elites and all other elites on the national, state, and local level. Statements made by labor leaders and labor organizations were excluded because it was assumed they were more directly tied to the unemployed and their statements about unemployment would be less likely to indicate any change in political environment. We were more concerned with the protest actions of the working and lower classes than with their statements. Overall, 1,526 elite statements were coded (598 of these by national level political elites).

As with the protest data, six years were randomly selected for recoding by the authors to check the coding accuracy of elite statements. The coding of elite statements proved to be a very difficult process for the "big years" (i.e., those years with 100 to 200 or more news articles containing elite statements). The New York Times Index was not always clear on whether or not a statement by an individual or organization was in the news article. Thus, judgment errors were made by coders, but primarily in big years. As a result, elite statements for the big years were underestimated, which produces a conservative estimate of the impact of elite statements. The years selected for recoding by the authors were 1908, 1913, 1920, 1921, 1922, and 1934. Overall coder agreement was 67 percent, and 72 percent for national political elites only. Excluding 1934 (a big year), however, coding agreement was 78 percent overall, and 92 percent for national level political elites. In addition, as in the case of protest data, we examined the San Francisco Chronicle during the time periods with high unemployment but few elite statements (i.e., 1894, 1896, and 1908). This qualitative comparison indicated no significant differences in the reporting of elite statements by these two newspapers. We should also note that the pattern of elite recognition generally follows the descriptions of historians (Garraty 1978 ).

Finally, the degree to which elections were closely contested was measured by the absolute value of the difference in votes cast for Republicans and Democrats for the House of Representatives (Thomas 1987). For off election years, values were interpolated from the election year data. ${ }^{2}$

2. Originally, the research reported here was expected to employ generalized least squares, with the CochraneOrcutt method of correcting for autocorrelation effects (Hibbs 1974; Kmenta 1971; Ostrom 1978). However, as will be seen in the figures presented, such a time-series analysis would be misleading. Our data conform to the description by Isaac and Griffin (1989) of the instability of the findings when using time-series analysis if there is primarily one major 


\section{Findings}

Figure 1 shows that the high rate of unemployment from 1893 to 1898 was not accompanied by a massive increase in protest activity. "Coxey's Army" of unemployed who marched on Washington was active during this period (Beals 1968; Feder 1936; Piven and Cloward 1977), but our data and the historical works report little other protest. For example, in his examination of the history of unemployment in Massachusetts, Keyssar (1986) describes a few protest activities in Boston during 1894 that were not picked up in our New York Times data, though we did include the one major demonstration on the Boston Commons that year. But most importantly, our data conform to Keyssar's (1986:222) conclusion that "during most years between 1870 and the early 1920s, the Commonwealth of Massachusetts did not witness any protests or demonstrations by unemployed workers. The protest movements that did arise, moreover, generally captured the support and allegiance of only a small proportion of the unemployed." In the two rather short recessions of 1908 and 1915, the data again show very little protest by the unemployed, and with the higher unemployment rates after World War I (reaching 11.9 percent in 1921) we find almost no reports of protest by the unemployed. From the very beginning of the Great Depression, however, the number of protests increased rapidly. In 1930, the unemployment rate had reached only 8.7 percent, but protest reached a point much higher than in any other previous period in our analysis, and continued racing upward until 1936.

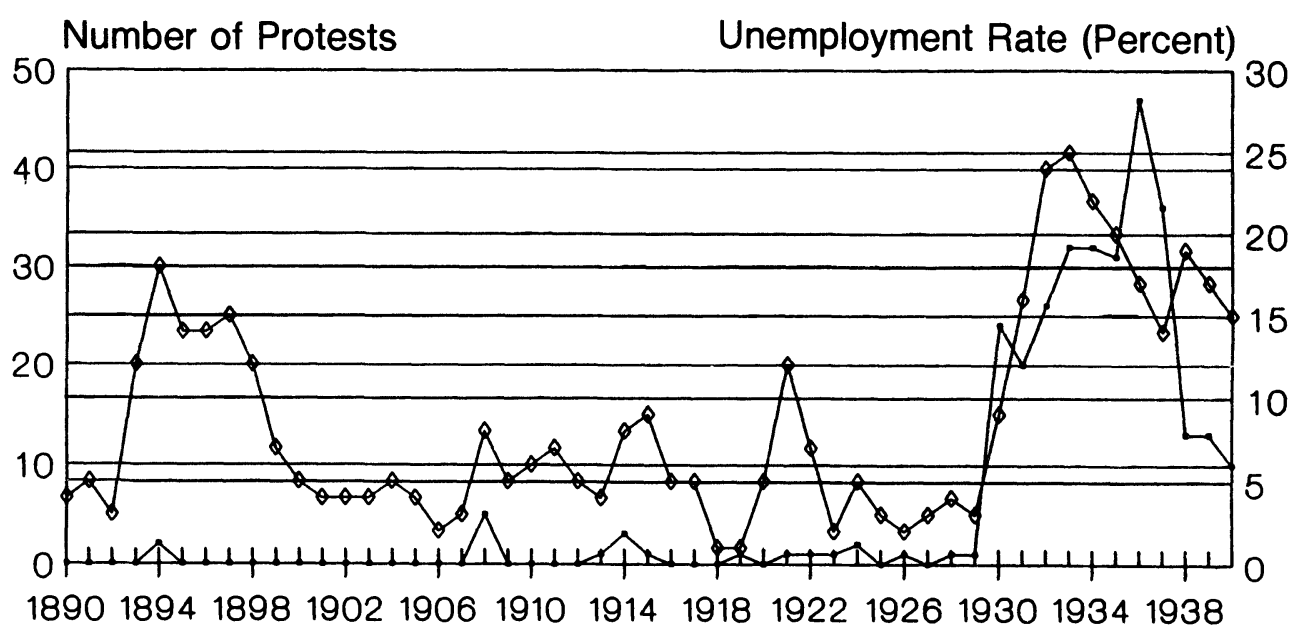

$\rightarrow$ Number of Protests Unemployment Rate

\section{Figure 1 - Protests and Unemployment Rate, 1890-1940}

This point must be emphasized-protest in the 1930s did not come after a prolonged level of high unemployment. It began from the very first year, before anyone knew that unemployment would be almost 25 percent in three years. It is also important to note that the estimated number of protestors involved (over 100,000) in 1930 was, with one exception, higher

period of change with respect to the variables measured for a longer historical period. By simply adding or dropping years from the period 1890 to 1940 we found wide swings in the regression figures, and thus could have selected a set of years that conformed to the findings we expected. As Isaac and Griffin (1989) point out, time-series analysis is designed to measure correlations over time, or trends in the relations between variables. But time-series analysis does not accurately model dramatic qualitative changes in history, for it incorrectly, in this case, presumes at least some continuity in historical events (see Isaac and Leicht 1990). 
than in any other year in the 1930s. ${ }^{3}$ Thus, it is clear that the severity of the depression of the 1930s was not the primary factor causing the massive level of protest; something happened prior to 1930 to set the stage for protest. Finally, after 1936, protest dropped rapidly, even in the face of an upturn in unemployment (reaching 19 percent in 1938).

Why do we find a high level of protest by the unemployed only in the 1930s? Was there a significant change in "political opportunities," as suggested in Jenkins and Perrow's (1977) analysis of the farm workers' movement in the 1960s and McAdam's (1982) analysis of the civil rights movement? Before the 1920s we find little mention of the problems of the unemployed by elites, even when unemployment reached almost 19 percent in the early 1890s. During the 1920s, however, this changed dramatically. Figure 2 indicates at least one change in the political process beginning in the 1920 s when elite statements about unemployment became very common even during periods of relatively low unemployment.

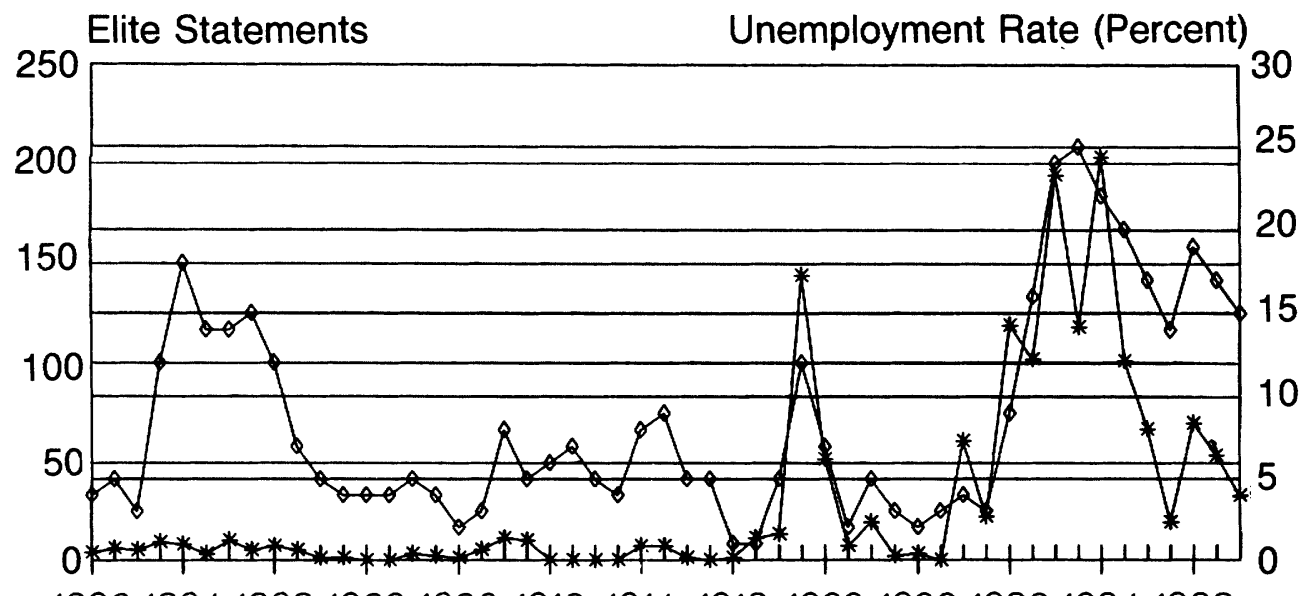

1890189418981902190619101914191819221926193019341938

\section{* Elite Statements $\rightarrow$ Unemployment Rate}

\section{Figure 2 - Unemployment and Elite Statements, 1890-1940}

It is important to know if the politicization of unemployment occurred mainly on the level of local politics, primarily on the national level, or both. Figure 3 indicates that it was both: national level political figures as well as state and local elites were making statements about unemployment at about the same time in the 1920s and 1930s. There are some differences indicated in Figure 3. In the election years of 1928 and 1930, but especially in 1928, national level elites took the lead in discussing the issue of unemployment. Interestingly, unemployment was first discussed extensively in a non-election year (1921), but then became a big issue next (with national elites especially) in 1928, an election year for the House, Senate, and presidency. It must also be noted, in 1928 unemployment was not even especially high. Nor was unemployment very high in 1930 (8 percent) when it was again a big national political issue, compared to unemployment levels two years later at the high point of the Depression in 1932-1933. Thus, it seems clear that in 1928, and again in 1930 and 1932,

3. Figure 1 presents only the number of protest events reported in the New York Times, rather than the estimated number of protestors involved. The estimated number of protestors reported involved in the annual total of each protest event in key years are as follows: $1894-500$ protestors; $1908-4,800 ; 1914-3,500 ; 1922-450 ; 1930-102,500 ; 1931-10,800 ; 1932-$ 63.700; 1933-73,450; 1934-19,900; 1935-41,300; 1936-29,400; 1937-49,400; 1938-39,250; 1939-113,900; 1940-670. The high number of protestors for 1939 was due to one nationwide protest in July by WPA workers protesting layoffs and cuts in the WPA program. 
unemployment became a major political issue, especially for national level elites, whether or not unemployment was especially high. Before turning to other data it will be useful to examine some of the explanations for the patterns found in Figures 2 and 3.

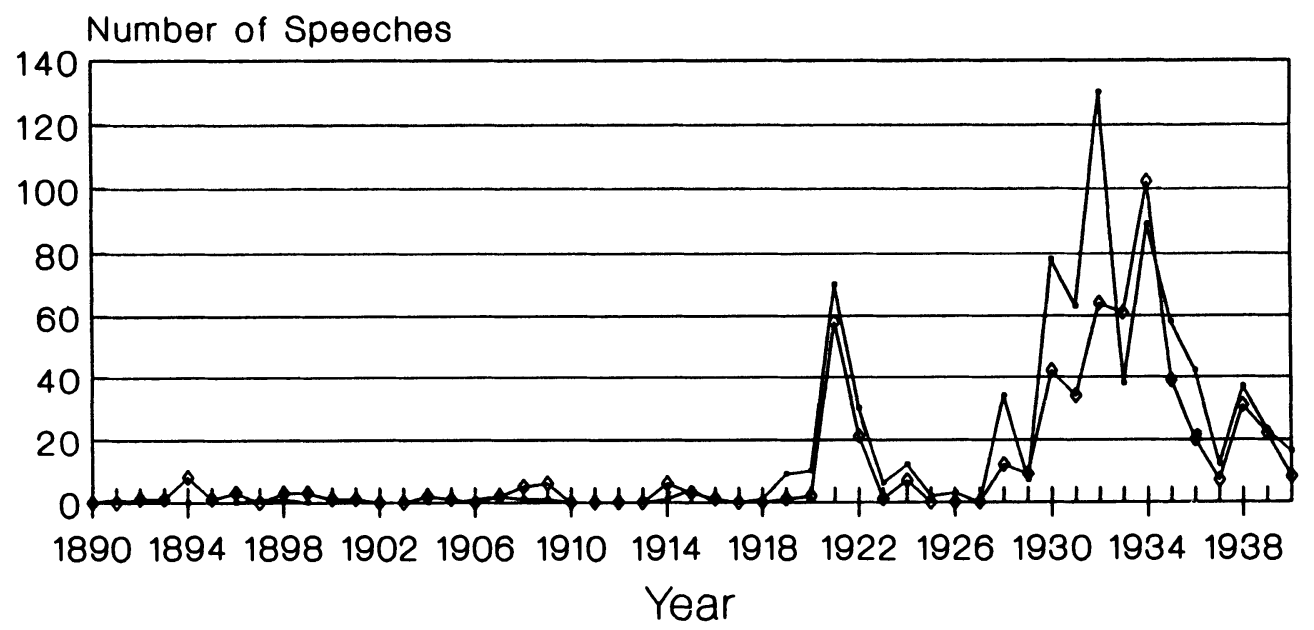

$\longrightarrow$ National Speeches $\rightarrow$ Local Speeches

Figure 3 - National vs. Local Speeches, 1890-1940

Piven and Cloward $(1977,1982)$ have argued that the working class and lower class groups were mobilized in the 1930s when the Democratic party sought the support of a new voter constituency. However, our data on elite statements indicate that at least some change in the political environment began in the 1920s. A revision of the Piven and Cloward thesis can be suggested. The progressive movement of the early 1900s helped elect a liberal Republican, Theodore Roosevelt, to the presidency, and then later provided a political base for Democrats (Goldman 1953; Hofstader 1955; Schlesinger 1957). In contrast to the earlier populist movement, the progressive movement was basically urban, and for the most part middle class. The major issues were economic concentration, big business dominance, local government corruption, and "robber barons." But the years after World War I brought an apparent collapse of the Progressive Era, and new conservative, Republican Presidents Harding, Coolidge, and Hoover. Not only did the Democrats lose the presidency in 1920, they lost control of both the House and Senate after the 1918 elections. Until the 1930s both bodies were controlled by Republicans, and by a big margin in the House. It was a time of extreme probusiness attitudes among political elites in power, and extensive repression of labor (Griffin, Wallace, and Rubin 1986) and of dissent in general (with the first major "red scare").

Ironically, our data show increased elite recognition of unemployment in the 1920s in spite of labor repression. This may be explained by the collapse of the progressive movement which was supporting the Democratic party before World War I. Major segments of the Democratic party began turning toward labor for political support (Schlesinger 1957), and one way to seek this support was through the politicization of working-class issues such as unemployment. Figures 2 and 3 indicate that this was particularly true in the 1928 election.

The data on elite statements is ambiguous on this point because both Republicans and Democrats made statements about unemployment. In fact, the issue of unemployment was first given extensive attention by Herbert Hoover in 1921 while he was Secretary of Commerce. Hoover persuaded President Harding to stage the "President's Conference on Unemployment" which was chaired by Hoover. However, Harding opened the 1921 Conference 
"by saying that the [1921] depression was inevitable, that anyone who thought planning might have averted it was deluding himself, and that, in particular, any plan involving government spending would only increase the trouble" (Schlesinger 1957:85). It can be argued that while elements of the Democratic party were going after the working-class vote with concerned statements about the unemployed, Republicans could not be silent on the issue even though they took a negative view toward government action to reduce unemployment. As we would expect, when Democrats tried to court working-class voters, Republicans mounted a counteroffensive. Thus we find both negative and positive statements about the unemployed increasing or decreasing simultaneously.

Whether or not this explanation is accepted, the data clearly show that unemployment became a major political issue for the first time in the 1920s, especially in the 1928, 1930, and 1932 election years. This politicization of unemployment was not brought about by workingclass revolt (as indicated by the low level of protest in the 1920s), nor did the politicization of unemployment prove to be an immediate stimulus to lower-class revolt.

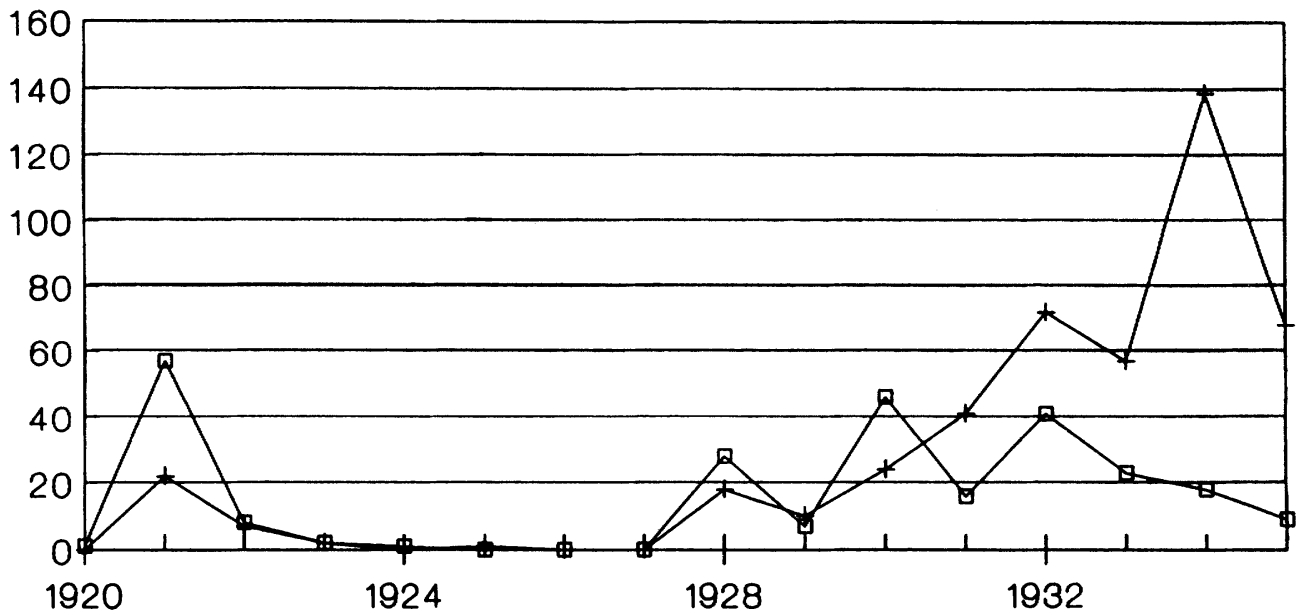

\section{$\rightarrow$ Speeches on Welfare $\rightarrow$ Speeches on Unemployment}

Figure 4 - Speeches on Unemployment and Welfare, 1920-1935

Figure 4 indicates that what was said about unemployment changed in the 1920s and 1930s, and influenced the political environment and the possibilities for mobilizing the unemployed. In the early years of the 1920s, the problem of unemployment was discussed, but aid programs for the unemployed were not a significant issue. By the end of the 1920s, however, aid programs were more widely discussed. Not only was the issue of unemployment politicized, but by the end of the 1920s the more specific issue of aid to the unemployed was also politicized. When unemployment began to grow significantly in 1930, the unemployed were listening not just to abstract discussions about government responsibility but to discussions of what could and should be done to aid them. Government aid for the unemployed seemed to be a growing possibility, but not yet a reality (except in a very limited way on the local level).

Finally, we must consider the impact of elections on protest activity by the unemployed. Figure 5 shows the absolute difference in votes cast for Republicans and Democrats (in millions of votes) from 1896 to 1940 . Non-election years were estimated from the previous and following voting years. During the 1920s we find that congressional elections were not very close. Republicans, except in 1922, won by large margins. But this started to change by the 


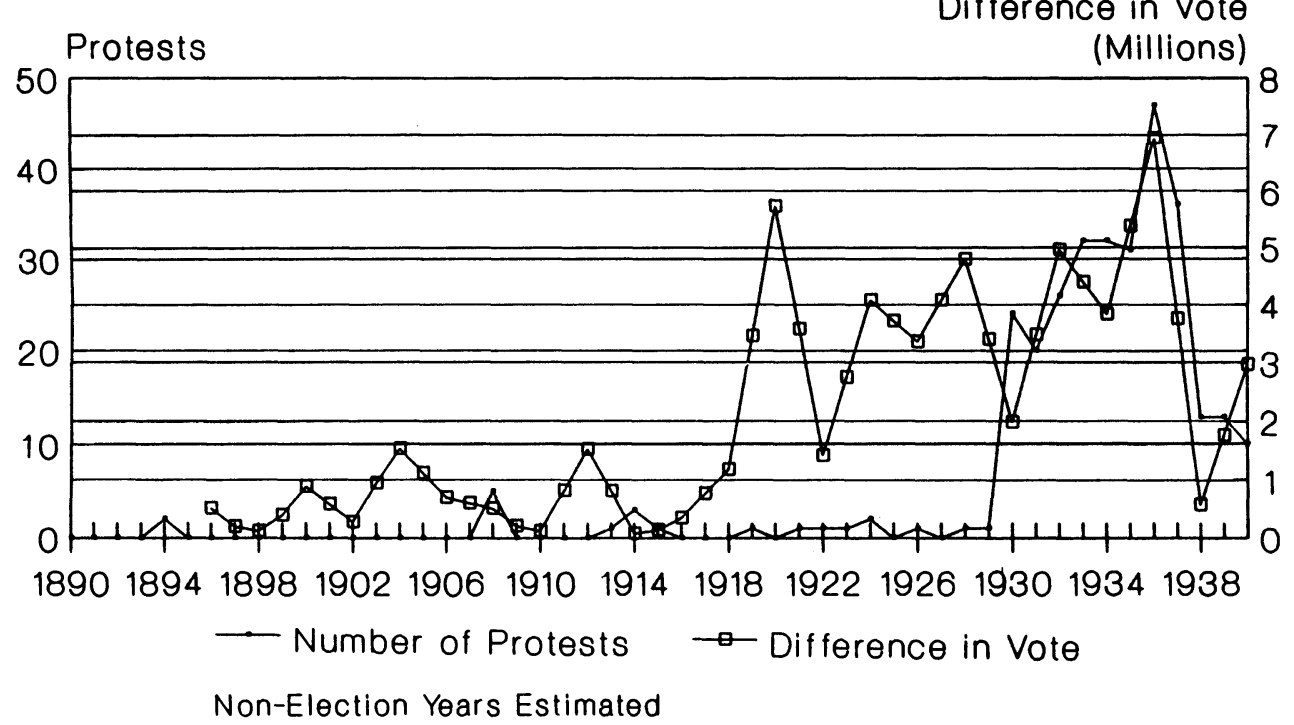

Figure 5 - Protests and the Closeness of Congressional Elections: 1890-1940

later years of the 1920s, with vote margins becoming much closer by 1930 , until they reversed with big Democratic margins in Roosevelt's landslide victory in 1932.

Tilly (1978) argues that social movements are more likely to occur during contested elections, or times that offer hope for political change. Figures 4 and 5 support Tilly's argument with respect to protest by the unemployed from the very beginning of the Great Depression. We have shown that protest by the unemployed was not related to unemployment levels between 1890 and 1940, nor was massive protest by the unemployed due to the severity and length of the Great Depression. When unemployment was first politicized in the early 1920s, usually by national level elites, discussion of government responsibility for economic conditions and unemployment was mainly at an abstract level. Figures 4 and 5, however, show that by 1930 conditions existed which, following Tilly, would lead to mobilization of protest by the unemployed. Rather than abstract discussion about unemployment, the late 1920s, and especially 1930 and 1932, brought specific discussions of aid to the unemployed. This suggests that, from the very first year of the Great Depression, the unemployed felt a sense of hope or belief in expanded opportunity, a condition stressed by Tilly. They believed something might actually be done to aid them. Moreover, by 1930 elections were again contested. The Republicans were no longer certain to control the federal government. Again, for the unemployed who had been told by conservative Republican politicians that nothing could be done, a ray of hope for activism may have appeared.

\section{Existing Social Movement Organizations}

Up to this point, our discussion has not touched on the effects of organizational efforts of various labor and left wing political groups during the late 1920s and early 1930s on protest activity by the unemployed. Recent critiques of the resource mobilization perspective have pointed out the neglect of face-to-face interaction in mobilizing movement participants (Hirsch 1990).

Piven and Cloward (1977:68) stress the absence of extensive organizing among the unemployed during the early 1930s, and they make the controversial argument that this lack of 
organization made it difficult for the "powers that be" to tame the movement. But there was some organization behind the rise of protest among the unemployed. Communist organizations, for example, formed Unemployed Councils as early as 1929 (Piven and Cloward 1977:68) to try to mobilize the unemployed. We find that these Unemployed Councils were important in the first protests in 1930. In fact, almost all of the protest activity indicated by our New York Times data during 1930 involved the Communist led Unemployed Councils, beginning with demonstrations in February of 1930 involving more than a thousand of the unemployed. In March, and especially during the summer months, similar demonstrations took place, though these demonstrations were smaller after February of 1930.

As we move to 1931 and 1932, the number of protests reported by the New York Times as organized by Communist or Socialist organizations drops, and protests organized by other groups (or with no group given credit) increases. By 1932, few of the demonstrations were reported as organized by Communist groups, and by the summer of 1932 the Veterans' Bonus Army took most of the headlines. Throughout the first half of the 1930s, the constant theme in the protests was the demand for government aid for the unemployed; the demand for jobs was the next most common issue.

Communist and Socialist organizations clearly helped mobilize the unemployed from the beginning of the 1930s. But a focus only on these organizational efforts tells us little about why massive protest by the unemployed for the first time in the history of the United States arose during the 1930s. In contrast to the 1930s, Communist groups tried to organize the unemployed during the 1920s with little success. For example, on February 12, 1922 a march for jobs led by a Communist group attracted between 200 and 300 participants. In January of 1923 and December of 1924, small protests by the unemployed were reportedly organized by Socialists seeking government aid. But these were the only recorded protests by the unemployed in these years; no others were recorded until 1928. During July of 1928, there was a very small protest involving fewer than 50 participants, then another in March of 1929, also involving fewer than 50 participants. It is not until 1930 that we find widespread protest.

Our data indicate that organizational work cannot be separated from the political environment of the time. The evidence strongly suggests that attempts to organize the unemployed at the beginning stages of the protest of the 1930s were only possible or successful because of the changes in political environment and opportunity described in this paper. We know that some attempts to organize the unemployed took place in even earlier periods of U.S. history (before the 1920s) with very little success (Garraty 1978; Keyssar 1986).

Additional evidence of the value of organizational networks in mobilizing social movement participants is found in our data for the late 1930s. Figure 1 indicates the number of protestors involved in protest activity was at its highest point in 1939 (see footnote 3). Our data on the issues behind the protests clearly show that most of the protest in 1936 and 1939 was carried out by former and current recipients of aid programs like those provided by the Works Progress Administration (WPA). In fact, the high number of protestors in 1939 can be primarily accounted for by one, highly organized, nationwide protest in July. In 1936, the year with the highest number of protests, slightly over half of all protests were by aid recipients over the issue of cuts in welfare programs such as the WPA. Most of the other protests in 1936 were calls for an increase in aid carried out by persons receiving some form of government assistance. Thus, protests in the late 1930s benefitted from the organization made possible by welfare programs which brought the unemployed together. These later protests over cuts in New Deal programs are best described in Tilly's (1978) terms as "reactive movements" rather than the "proactive movements" of the earlier 1930s. The "proactive movements" in the early 1930s, which sought new opportunities in a changed political environment during elections, best fit Tilly's (1978) "power struggles" thesis of social movements. 


\section{Discussion}

Deprivation alone, as measured by the unemployment rate, is not sufficient to generate significant protest. This conclusion seems obvious from Figure 1. Extensive protest by the unemployed emerged with increasing unemployment for the first time in 1930. Yet this occurred when unemployment was not especially high compared to several other time periods from 1890 to 1940, and before it was clear that the Great Depression was under way. It was not extensive deprivation, which was yet to come, but some change in the political environment which took place by 1930 that helped bring about mass mobilization of the unemployed for the first time. As pointed out in the beginning of this paper, however, the concept of political environment in the social movement literature is currently rather ambiguous. Tarrow (1988), for example, has noted that while political environment is an important variable effecting the mobilization of protest, the concept needs further specification and refinement. Political environment can refer to a cluster of variables, some of which involve material support, while others imply attitudinal effects such as "cognitive liberation," "legitimation," or simply the realization by potential movement members that change is more possible than in previous periods. Still other aspects of political environment imply all of the above, such as Tilly's "power struggles" thesis which suggests that hope for change can help mobilize activists. Tilly also cites tangible political shifts, such as less repression and support from political actors who see aid to the social movement as assisting in the defeat of political opponents. More research is needed to determine which elements of political environment are most important, and even whether they can be measured separately, as opposed to being conceptualized as separate.

The research reported here represents an attempt to settle some of these issues by measuring some often cited aspects of political environment and their connections to mobilization by the unemployed. Our findings, combined with those of some other researchers on this subject, lead us to suggest that perceived opportunities for change among social movement members were the main stimuli for mobilization from the very beginning of the Great Depression. Legitimization of the issue of unemployment first occurred as early as 1921, and remained relatively high throughout the 1920s and 1930s. However, significant protest did not occur until 1930. By the end of the 1920s, but especially in the 1930 to 1932 period, two crucial factors came together for the first time with respect to the issue of unemployment. First, by the late 1920s, public statements by elites had moved beyond simple discussions of unemployment as a problem to the actual means of aiding the unemployed. Second, beginning in the late 1920s, but especially in 1930, elections were again contested. Greater opportunities existed to remove politicians who were not inclined to support aid programs. A third factor related to these two factors is found in research by Jenkins and Brents (1989), Quadagno (1984, 1988), and Domhoff (1990). In focusing on elite involvement in the development of 1930s welfare programs, these researchers found that the elite was split over the issue of welfare aid. Our research, using the New York Times as a data source, indicates that non-elites should have been aware of this elite split and that new and expanded welfare programs would come only if the elite faction in favor of such programs was successful in shaping policy. Such a realization should have presented an opportunity and stimulus for mobilizing the unemployed.

There is, of course, an old debate in the social movement literature over whether we should assume potential social movement members are primarily rational actors. The assumption of rationality need not be taken too far to argue that the combination of factors listed above was enough to suggest to potential social movement members (the unemployed) and their leaders that the possibility of change was present in 1930. With the very first rise in unemployment in 1930, the movement of the unemployed took off as never before in U.S. history. But this was not because prolonged or very high unemployment rates were creating 
more hardship; rather, the impetus was the change in political environment outlined in this paper.

\section{References}

Beals, Carleton

1968 The Great Revolt and Its Leaders. New York: Abellard-Schuman.

$\rightarrow$ Danzger, M. Herbert

1975 "Validating conflict data." American Sociological Review 40:570-584.

Domhoff, G. William

1990 The Power Elite and the State. New York: Aldine de Gruyter.

Feder, Leah Hannah

1936 Unemployment in History: Economic Thought and Public Policy. New York: Harper and Row.

Gamson, William A.

1975 The Strategy of Social Protest. Homewood, Ill.: Dorsey Press.

Garraty, John

1978 Unemployment in History: Economic Thought and Public Policy. New York: Harper and Row.

Goldman, Eric F.

1953 Rendezvous with Destiny. New York: Alfred Knopf.

$\rightarrow$ Goldstone, Jack

1980 "The weakness of organization: A new look at Gamson's 'The Strategy of Social Protest." American Journal of Sociology 85:1017-1042.

$\rightarrow 1986$ "State breakdowns in the English Revolution: A new synthesis." American Journal of Sociology 92:257-322.

$\rightarrow$ Griffin, Larry, Michael Wallace, and Beth Rubin

1986 "Capitalist resistance to the organization of labor before the New Deal: Why? how? success?" American Sociological Review 51:147-167.

Hibbs, Douglas A., Jr.

1974 "Problems of statistical estimation and causal inference in time series, regression models." In Sociological Methodology, ed. Herbert Costner, 252-308. San Francisco: Jossey-Bass.

$\rightarrow$ Hirsch, Eric L.

1990 "Sacrifice for the cause: Group processes, recruitment and commitment in a student social movement." American Sociological Review 55:243-254.

Hofstader, Richard

1955 The Age of Reform: From Bryan to FDR. New York: Knopf.

$\rightarrow$ Isaac, Larry W., and Larry J. Griffin

1989 "Ahistoricism in time-series analyses of historical process: Critique, redirection, and illustrations from U.S. labor history." American Sociological Review 54:837-890.

Isaac, Larry, and Kevin T. Leicht

1990 "Historical sociology and the quality of quantity: Historical contingency, turning points and regimes in the U.S. 'welfare-warfare state.'" Paper given at the annual meetings of the Southern Sociological Society, March, Louisville, Kentucky.

$\rightarrow$ Jenkins, J. Craig, and Barbara G. Brents

1989 "Social protest, hegemonic competition and social reform: A political struggle interpretation of the American welfare state." American Sociological Review 54:891-909.

$\rightarrow$ Jenkins, J. Craig, and Craig Eckert

1986 "Channeling black insurgency: Elite patronage and professional social movement organizations in the development of the black movement." American Sociological Review 51:812-829. 
$\rightarrow$ Jenkins, J. Craig, and Charles Perrow

1977 "Insurgency of the powerless: Farm worker movements, 1946-1972." American Sociological Review 42:249-267.

$\rightarrow$ Kerbo, Harold R.

1982 "Movements of 'crisis' and movements of 'affluence': A critique of deprivation and resource mobilization theories of social movements." Journal of Conflict Resolution 26:645-663.

$\rightarrow$ Kerbo, Harold R., and Richard A. Shaffer

1986 "Unemployment and protest in the United States, 1890-1940: A methodological critique and research note." Social Forces 64:1046-1056.

Keyssar, Alexander

1986 Out of Work: The First Century of Employment in Massachusetts. Cambridge: Cambridge University Press.

Kielbowicz, R.B., and C. Scherer

1986 "The role of the press in the dynamics of social movements." Research in Social Movements, Conflict, and Change 9:71-96.

$\rightarrow$ Klandermans, Bert

1984 "Mobilization and participation: Social-psychological explanations of resource mobilization theory." American Sociological Review 49:583-600.

Kmenta, Jan

1971 Elements of Econometrics. New York: MacMillan.

McAdam, Doug

1982 Political Process and the Development of Black Insurgency: 1930-1970. Chicago:

University of Chicago Press.

$\rightarrow 1983$ "Tactical innovation and the pace of insurgency." American Sociological Review 48:735754.

$\rightarrow$ McCarthy, John D., and Mayer N. Zald

1977 "Resource mobilization and social movements: A partial theory." American Journal of Sociology 82:1212-1241.

Oberschall, Anthony

1973 Social Conflict and Social Movements. Englewood Cliffs, N.J.: Prentice-Hall.

$\rightarrow$ Oliver, Pamela

1980 "Rewards and punishments as selective incentives for collective action: Theoretical investigations." American Journal of Sociology 85:1356-1375.

Olson, Mancur Jr.

1965 The Logic of Collective Action: Public Goods and the Theory of Groups. Cambridge, Mass.: Harvard University Press.

Olzak, Susan

1989 "Analysis of events in the study of collective action." Annual Review of Sociology 15:119-141.

Ostrom, Charles W., Jr.

1978 Time Series Analyses: Representation Techniques. Beverly Hills, Calif.: Sage.

Paige, Jeffrey

1975 Agrarian Revolution. New York: Free Press.

Piven, Frances Fox, and Richard Cloward

1971 Regulating the Poor: The Functions of Public Welfare. New York: Pantheon Books.

1977 Poor People's Movements: When They Succeed, Why They Fail. New York: Pantheon Books.

1982 The New Class War. New York: Pantheon Books.

$\rightarrow$ Quadagno, Jill S.

1984 "Welfare capitalism and the Social Security Act of 1935." American Sociological Review 49:632-647.

1988 The Transformation of Old-Age Security: Class and Politics in the American Welfare State. Chicago: University of Chicago Press.

Schlesinger, Arthur $\mathbf{M}$.

1957 The Age of Roosevelt I: The Crisis of the Old Order. Boston: Houghton Mifflin.

1959 The Age of Roosevelt II: The Coming of the New Deal. Boston: Houghton Mifflin. 
1960 The Age of Roosevelt III: The Politics of Upheaval. Boston: Houghton Mifflin.

$\rightarrow$ Snyder, David

1975 "Institutional setting and industrial conflict: Comparative analyses of France, Italy and the United States." American Sociological Review 40:259-278.

$\rightarrow$ Snyder, David, and William Kelly

1977 "Conflict intensity, media sensitivity and validity of newspaper data." American Sociological Review 42:105-123.

$\rightarrow$ Snyder, David, and Charles Tilly

1972 "Hardship and collective violence in France, 1830 to 1960." American Sociological Review 37:520-532.

Stohl, Michael

1976 War and Domestic Political Violence: The American Capacity for Repression and Reaction. Beverly Hills, Calif.: Sage Publications.

$\rightarrow$ Tarrow, Sidney

1988 "National politics and collective action: Recent theory and research in Western Europe and the United States." Annual Review of Sociology 14:421-440.

Thomas, G. Scott

1987 The Pursuit of the White House: A Handbook of Presidential Election Statistics and History. N.Y.: Greenwood Press.

Tilly, Charles

1978 From Mobilization to Revolution. Reading, Mass.: Addison-Wesley.

1984 "Social movements and national politics." In Statemaking and Social Movements, ed. Charles Bright and Susan Harding, 297-317. Ann Arbor, Mich.: University of Michigan Press.

Tilly, Charles, Louis Tilly, and Richard Tilly

1975 The Rebellious Century. Cambridge, Mass.: Harvard University Press.

U. S. Bureau of the Census

1975 Historical Statistics of the United States, Colonial Times to 1970, Parts 1 and 2.

Washington, D.C.: U.S. Government Printing Office. 